\title{
Effect of some operational parameters on the arsenic removal by electrocoagulation using iron electrodes
}

\author{
Berrin Zeliha Can ${ }^{1}$, Recep Boncukcuoglu ${ }^{2 *}$, Alper Erdem Yilmaz² and Baybars Ali Fil ${ }^{2,3}$
}

\begin{abstract}
Arsenic contamination of drinking water is a global problem that will likely become more apparent in future years as scientists and engineers measure the true extent of the problem. Arsenic poisoning is preventable though as there are several methods for easily removing even trace amounts of arsenic from drinking water. In the present study, electrocoagulation was evaluated as a treatment technology for arsenic removal from aqueous solutions. The effects of parameters such as initial pH, current density, initial concentration, supporting electrolyte type and stirring speed on removal efficiency were investigated. It has been observed that initial pH was highly effective on the arsenic removal efficiency. The highest removal efficiency was observed at initial pH=4. The obtained experimental results showed that the efficiency of arsenic removal increased with increasing current density and decreased with increasing arsenic concentration in the solution. Supporting electrolyte had not significant effects on removal, adding supporting electrolyte decreased energy consumption. The effect of stirring speed on removal efficiency was investigated and the best removal efficiency was at the $150 \mathrm{rpm}$. Under the optimum conditions of initial pH 4, current density of $0.54 \mathrm{~mA} / \mathrm{cm}^{2}$, stirring speed of $150 \mathrm{rpm}$, electrolysis time of 30 minutes, removal was obtained as $99.50 \%$. Energy consumption in the above conditions was calculated as $0.33 \mathrm{kWh} / \mathrm{m}^{3}$. Electrocoagulation with iron electrodes was able to bring down $50 \mathrm{mg} / \mathrm{L}$ arsenic concentration to less than $10 \mu \mathrm{g} / \mathrm{L}$ at the end of electrolysis time of 45 minutes with low electrical energy consumption as $0.52 \mathrm{kWh} / \mathrm{m}^{3}$.
\end{abstract}

Keywords: Arsenic removal, Electrocoagulation, Wastewater treatment, Iron electrode

\section{Introduction}

Arsenic, a toxic trace element present in natural waters (ground and surface water), has become a major unavoidable threat for the life of human beings and useful microorganisms. Arsenic concentration in water can become elevated due to several reasons like, mineral dissolution, use of arsenical pesticides, disposal of fly ash, mine drainage and geothermal discharge [1]. Arsenic can exist in four different oxidation states: (-III), (0), (III), and (V), however, oxidized arsenite $(\mathrm{As}(\mathrm{III}))$ and arsenate $(\mathrm{As}(\mathrm{V}))$ are the most widespread forms in soils and natural waters [2]. Under low $\mathrm{pH}$ and mildly reducing conditions $(>100 \mathrm{mV})$, As(III) is thermodynamically stable and exists as arsenious acid $\left(\mathrm{H}_{3} \mathrm{AsO}_{3}, \mathrm{H}_{2} \mathrm{AsO}_{3}{ }^{-}, \mathrm{HAsO}_{3}{ }^{2-}\right.$ and $\left.\mathrm{AsO}_{3}{ }^{3-}\right)$. Under oxidizing conditions, the predominant species is $\mathrm{As}(\mathrm{V})$

\footnotetext{
*Correspondence: rboncuk@atauni.edu.tr

${ }^{2}$ Department of Environmental Engineering, Engineering Faculty, Atatürk

University, Erzurum, Turkey

Full list of author information is available at the end of the article
}

which exists as arsenic acid $\left(\mathrm{H}_{3} \mathrm{AsO}_{4}, \mathrm{H}_{2} \mathrm{AsO}_{4}{ }^{-}, \mathrm{HAsO}_{4}{ }^{2-}\right.$ and $\mathrm{AsO}_{4}{ }^{3-}$ ) [2]. $\mathrm{As}(\mathrm{III})$ is more mobile in groundwater and 25-60 times more toxic than $\mathrm{As}(\mathrm{V})$. The concentration of arsenic species is mainly dependent on redox potentials and $\mathrm{pH}[3]$.

Arsenic contamination in potable water supplies is a serious health problem in many countries around the world. As it causes to skin, liver, lung and kidney or bladder cancer, it is a big headache to the nations [4]. Due to carcinogenic nature of arsenic compounds, the purpose should now be to reduce the concentration of arseniccontaminated water to a level as close to zero as possible. By the World Health Organization, the provisional guideline value for arsenic in drinking water is given as $10 \mu \mathrm{g} / \mathrm{L}$ as a provisional guideline value [5]. Therefore, the drinking water containing arsenic should be treated before usage. Several methods have been investigated for removal of arsenic, including ion exchange [6,7], coagulation and

\section{Biomed Central}


precipitation with iron and aluminum salts [8], adsorption [9-11], electrocoagulation [12-15], membrane techniques like ultrafiltration [16,17], nanofiltration [18], electrodialysis [19], reverse osmosis [13,20,21]. Other techniques like solvent extraction [22], bioremediation [23,24] have been developed for the removal of arsenic too.

In recent years, new processes for efficient and adequate treatment of various industrial wastewaters with relatively low operating costs have been needed due to strict environmental regulations. At this point, the electrocoagulation process has attracted a great deal of attention in treating industrial wastewaters because of its versatility and environmental compatibility $[25,26]$. Electrocoagulation consists of an in situ generation of coagulants by an electrical dissolution of iron or aluminum electrodes. The metal ions generation takes place at the anode; hydrogen gas is released from the cathode. The hydrogen gas would also help to float the flocculated particles out of the water and therefore the process sometimes is named as electroflocculation [27]. Typically, aluminum, iron, carbon, mild steel, graphite and titanium plates are used as electrodes in the electrocoagulation process. But iron and aluminum have been reported to be very effective and successful in pollutant removal at favorable operating conditions. In the iron electrode two mechanisms have been proposed for the production of iron hydroxide, $\mathrm{Fe}(\mathrm{OH})_{n}$ where $\mathrm{n}=2$ or 3 [28]:

- Mechanism 1.

Anode:

$4 F e_{(s)} \rightarrow 4 F e^{2+}{ }_{(a q)}+8 e^{-}$

$4 \mathrm{Fe}^{2+}{ }_{(a q)}+10 \mathrm{H}_{2} \mathrm{O}_{(l)}+\mathrm{O}_{2(g)} \rightarrow 4 \mathrm{Fe}(\mathrm{OH})_{3(s)}+8 \mathrm{H}^{+}{ }_{(a q)}$

Cathode:

$8 H^{+}{ }_{(a q)}+8 e^{-} \rightarrow 4 H_{2(g)}$

Overall:

$4 \mathrm{Fe}_{(s)}+10 \mathrm{H}_{2} \mathrm{O}_{(l)}+\mathrm{O}_{2(g)} \rightarrow 4 \mathrm{Fe}(\mathrm{OH})_{3(s)}+4 \mathrm{H}_{2(g)}$

- Mechanism 2.

Anode:

$\mathrm{Fe}_{(s)} \rightarrow \mathrm{Fe}^{2+}{ }_{(a q)}+2 e^{-}$
$\mathrm{Fe}^{2+}{ }_{(a q)}+2 \mathrm{OH}^{-}{ }_{(a q)} \rightarrow \mathrm{Fe}(\mathrm{OH})_{2(s)}$

Cathode:

$2 \mathrm{H}_{2} \mathrm{O}_{(l)}+2 e^{-} \rightarrow \mathrm{H}_{2(g)}+2 \mathrm{OH}^{-}(a q)$

Overall:

$\mathrm{Fe}_{(s)}+2 \mathrm{H}_{2} \mathrm{O}_{(l)} \rightarrow \mathrm{Fe}(\mathrm{OH})_{2(s)}+\mathrm{H}_{2(g)}$
Electrocoagulation is an emerging water treatment technology and could be a good choice to remove As (III) from water: the amount of required chemicals is much lower, a smaller amount of sludge is produced, no mixing of chemical is required, coagulant dosing as well required over potentials can be easily calculated and controlled, operating costs are much lower when compared with most of the conventional Technologies $[29,30]$. It is felt that As(III) might be oxidized to As(V) during electrocoagulation and gets adsorbed on to the metal hydroxides generated. Electrocoagulation has been successfully used to treat arsenic waste waters, with removal efficiencies as high as $90-99 \%[1,13,14,31]$. It was found that the rate of removal depends on the different operational parameters including initial concentration of arsenic, current density, the influence of $\mathrm{pH}$ and electrolysis time. Also groundwater could be cleaned for arsenic by electrochemical generated iron cations by Parga et al. [14]. Hansen et al. found analyzing preliminarily the electrocoagulation process in a modified flow sedimentation basin that it could be obtained a removal of 98\% from a $100 \mathrm{ppm}$ As solution [15]. Laboratory scale experiments to remove arsenic by the electrocoagulation process were conducted with three types of electrodes, namely iron, aluminum, and titanium [12]. The highest removal of arsenic (99\%) was obtained by using iron electrodes at a $\mathrm{pH}$ range of $6-8$. It may be because of high adsorption capacity of hydrous ferric oxides for arsenic removal. It was noted that As (III) removal mechanism in EC process seems to be oxidation of As (III) to As (V) and subsequence adsorption on to hydrous ferric oxides. As (III) oxidation to $\mathrm{As}(\mathrm{V})$ has previously been proposed to occur with dissolved oxygen and soluble intermediates in Fe(II) oxidation acting as rate enhancing species. As (III) oxidation can also occur when $\mathrm{Fe}(\mathrm{II})$ is present with $\mathrm{Fe}(\mathrm{III})$ oxyhydroxides, and the mechanism has been proposed to involve the formation of reactive Fe intermediate species.

The results on the investigation of the electrocoagulation process for treatment of arsenic indicated that using an electrocoagulation reactor successfully removes arsenic from water or wastewater. Therefore, the purpose of the present study was to investigate the effect of various operational parameters such as initial $\mathrm{pH}(2,3,4,5$, 6,7 and 8), electrolysis time $(0,3,5,10,20,30,45$ and 60 minute), current density $\left(0.18 \mathrm{~mA} / \mathrm{cm}^{2}, 0.36 \mathrm{~mA} /\right.$ $\mathrm{cm}^{2}, 0.54 \mathrm{~mA} / \mathrm{cm}^{2}, 0.71 \mathrm{~mA} / \mathrm{cm}^{2}, 0.89 \mathrm{~mA} / \mathrm{cm}^{2}$ and $\left.1.07 \mathrm{~mA} / \mathrm{cm}^{2}\right)$, initial arsenic concentration $(10 \mathrm{mg} / \mathrm{L}$ As, $25 \mathrm{mg} / \mathrm{L} \mathrm{As}, 50 \mathrm{mg} / \mathrm{L}$ As and $100 \mathrm{mg} / \mathrm{L} \mathrm{As}$ ), supporting electrolyte type $\left(\mathrm{Na}_{2} \mathrm{SO}_{4}, \mathrm{NaCI}\right.$ and $\left.\mathrm{KCI}\right)$ and stirring speed $(50 \mathrm{rpm}, 150 \mathrm{rpm}, 250 \mathrm{rpm}$ and 350 $\mathrm{rpm}$ ) on the arsenic removal using electrocoagulation method. 


\section{Materials and methods Materials}

All chemicals were of analytical grade and supplied by Merck and Panreac. Stock arsenic solutions of $1.3 \mathrm{~g} / \mathrm{L}$ were prepared by dissolving arsenic oxide $\left(\mathrm{As}_{2} \mathrm{O}_{3}\right)$ in $2 \mathrm{~N}$ $\mathrm{NaOH}$ and then diluted the solution up to 1 liter with de-ionized water. Solutions of lower concentrations were prepared by proper dilution. The $\mathrm{pH}$ of the solution was adjusted by adding either concentrated $\mathrm{NaOH}$ or $\mathrm{H}_{2} \mathrm{SO}_{4}$.

\section{Analytical methods}

The concentration of As was determined by an atomic absorption spectrophotometer (AAS) model Shimadzu AA 6800 equipped with a hydride generation. Hydride generation is, perhaps, the most popular sample derivatization method used for inorganic arsenic detection, since Holak first reported it in 1969 [32]. Initially it was developed as a method for AAS, whereby sodium or potassium tetrahydroborate (III) is used for arsine production (Eq. 9, 10). The reduction reagents $\mathrm{NaBH}_{4}$ and $\mathrm{KBH}_{4}$ have proved to be exceptionally reliable reagents for the conversion of the sample to volatile forms [33]. The hydride generation procedure can be also used for differential determination of As (III) and As (V), based on the fact that As (III) reacts with tetrahydroborate at a higher $\mathrm{pH}$ than As (V). Thus tetrahydroborate is acting as a reductant for As (V) as well as a hydride source. The inclusion of on-line hydride generation generally increases the sensitivity of detection and reduces the possible interferences from the sample matrix. In this study sodium tetrahydroborate $\left(\mathrm{NaBH}_{4}\right)$ was of analytical grade (Merck) and was dissolved in sodium hydroxide solution just before use.

$$
\mathrm{As}(\mathrm{OH})_{3}+3 \mathrm{BH}_{4}{ }^{-}+3 \mathrm{H}^{+} \rightarrow \mathrm{AsH}_{3}+3 \mathrm{BH}_{3}+3 \mathrm{H}_{2} \mathrm{O}
$$

$$
\mathrm{BH}_{3}+3 \mathrm{H}_{2} \mathrm{O} \rightarrow \mathrm{H}_{3} \mathrm{BO}_{3}+3 \mathrm{H}_{2}
$$

The removal efficiency of As in solution treated by electrocoagulation is calculated as follows:

$$
\eta(\%)=\frac{C_{0}-C_{t}}{C_{0}} \times 100
$$

where, $\eta$ is arsenic removal efficiency, $C_{0}$, and $C_{t}$ are the initial arsenic concentration and concentration of arsenic at time $t$ in solution $(\mathrm{mg} / \mathrm{L})$, respectively. The energy consumption was calculated by the following equation [34];

$$
E\left(\mathrm{kWh} / \mathrm{m}^{3}\right)=\frac{I x V x t}{v}
$$

where, $E$ is electrical energy consumption $\left(\mathrm{kWh} / \mathrm{m}^{3}\right), V$ is potential (volt), $I$ is current (ampere), $t$ is electrolysis time ( $\mathrm{min})$ and $v$ is volume of the solution $\left(\mathrm{m}^{3}\right)$. The relative standart deviation during arsenic analysis was in the range of $0-2 \%$.

\section{Electrocoagulation test}

The experiments carried out in a $1400 \mathrm{~mL}$ laboratory-scale batch reactor made of plexiglass. Two groups of alternating electrodes being cathodes and anodes (by six plates of each type) made of iron with total area of approximately $1400 \mathrm{~cm}^{2}$ were arranged vertically. The net spacing between the iron electrodes was $0.5 \mathrm{~cm}$. They were treated with the solution of $\mathrm{HNO}_{3}$ for cleaning prior to use. At the end of run, the electrodes were washed thoroughly with water to remove any solid residues on the surfaces, and dried. Electrodes were connected to a digital DC power supply characterized by the ranges $0-12$ A for current and 0-30V for voltage in monopolar mode. Cell current was measured using Brymen BM-810 multimeter. During the experiments, the electrocoagulation unit was stirred at predetermined speed by a magnetic stirrer (Heidolph MR-3004). The $\mathrm{pH}$ and conductivity were measured by a multimeter (WTW, Multiline 340i), which was freshly calibrated by 2 points $(4.01 ; 7.00)$ before each test. The experimental apparatus is given in Figure 1.

The reactor was fed with $1400 \mathrm{~mL}$ of arsenic containing solution at the beginning of each run. The experiment was started by switching the DC power supply on, and then the residual arsenic concentration in samples taken and filtered at predetermined time intervals was measured. The samples were analyzed by atomic absorption spectroscopy (Shimadzu AA 6800) with a hydride generation. In electrocoagulation studies, initial $\mathrm{pH}$, electrolysis time, current density, initial arsenic concentration, supporting electrolyte type and stirring speed were used as parameters whose values are given in Table 1.

\section{Results and discussion \\ Effect of initial $\mathrm{pH}$}

Initial $\mathrm{pH}$ is one of the important factors in affecting the performance of electrochemical process, increased during the study. To investigate this effect, a series of experiments performed under conditions of which values are given in Table 1. The results are presented in Figure 2. Initial $\mathrm{pH}$ of the solution affected the arsenic removal efficiency. At initial $\mathrm{pH}$ values with the range 2-8, current density of $0.54 \mathrm{~mA} / \mathrm{cm}^{2}$, stirring speed of $150 \mathrm{rpm}$, arsenic removal efficiency was obtained as $63.00 \%$, $95.00 \%, 97.00 \%, 92.50 \%, 89.50 \%, 88.00 \%, 84.00 \%$, respectively at the end of 20 minutes. Under these conditions at initial $\mathrm{pH}$ values with the range 3-8, arsenic removal efficiency was reached above $99.00 \%$ at the end of 30 minutes. Even, at initial $\mathrm{pH}$ of 2 in which removal efficiency was lower than the others, arsenic removal 


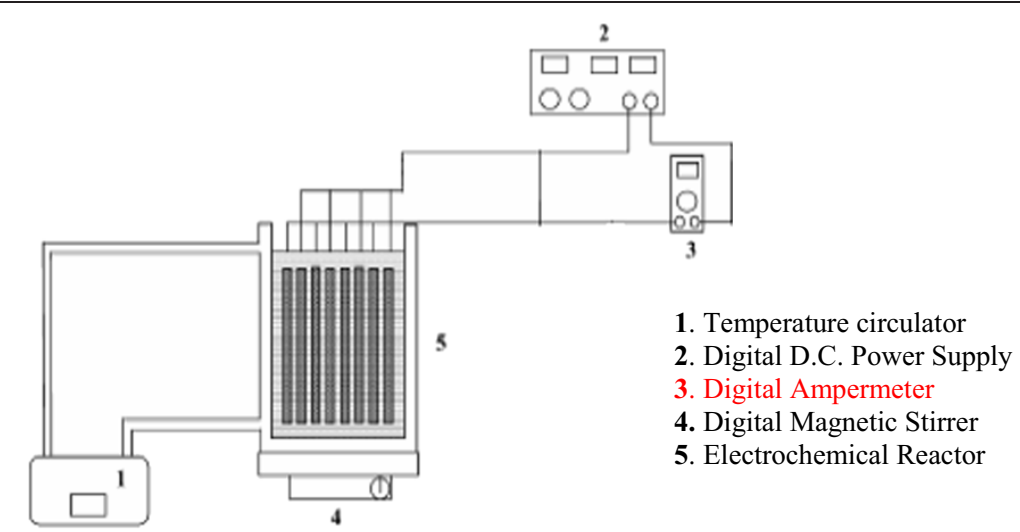

Figure 1 Schematic diagram of the experimental setup.

efficiency was reached as $76 \%$ at the end of 30 minutes. At all initial pHs it was reached removal efficiency of $99.99 \%$ at the end of 60 minutes.

Solubility of metal hydroxide species (both arsenic and iron hydroxides) strongly depends on the chemistry of the aqueous media. Removal of arsenic by electrocoagulation is significantly affected by solution $\mathrm{pH}$. Both initial $\mathrm{pH}$ and the elevation of $\mathrm{pH}$ during electrocoagulation affect arsenic solubility and hence its removal. For better understanding of this situation, changes in $\mathrm{pH}$ of the solution during the process in the all experiments were observed and presented in Figure 3. As shown in Figure 3, the pH value increases as the time of electrocoagulation process is increased.

This happened because the $\mathrm{OH}^{-}$ion accumulates in aqueous solution during the process. At the beginning $\mathrm{pH}$ increased rapidly and after a while it stopped when it reached to over 10.50 (initial $\mathrm{pH}$ of 4-8). Arsenic removal depends on both the initial and final $\mathrm{pH}$ of solution. Solubility diagram of iron (Fe(II), Fe(III)) according to $\mathrm{pH}$ and speciation of arsenite and arsenate (As(III) and $\mathrm{As}(\mathrm{V}))$ as a function of $\mathrm{pH}$ were given in Figures 4, 5 and 6, respectively $[35,36]$. As shown in Figure 4 , the resolution of Fe $(\mathrm{OH})_{3}$ is constant in all $\mathrm{pH}$ and its value is $10^{-9} \cdot \mathrm{Fe}(\mathrm{OH})_{2}$ begins to form at approximately $\mathrm{pH} 5$.
As a result of using iron electrodes in electrocoagulation, $\mathrm{Fe}^{2+}$ and $\mathrm{Fe}^{3+}$ ionswere produced by anodic dissolution and $\mathrm{Fe}(\mathrm{OH})_{2}$ and $\mathrm{Fe}(\mathrm{OH})_{3}$ flocks developed in the medium. Two mechanisms of the production of formed iron hydroxide were given in the 1-8 reactions [28]. It has been reported that in all the type of iron hydroxide, Fe $(\mathrm{OH})_{3}$ may collapse and has effective in flock formation and adsorbe the pollutants. The best removal efficiency was obtained in $\mathrm{pH}$ of $8.0-8.5$ in which $\mathrm{Fe}(\mathrm{OH})_{3}$ is the most stable. In this study, the reason of the significant increase of the removal of arsenic ions is due to the formation of the flocks of $\mathrm{Fe}(\mathrm{OH})_{3(\mathrm{~s})}$ during electrolysis.

The chemistry of arsenic is quite complex and interesting, as it can be stable in four oxidation states, continue changing its states and its removal is dependent on $\mathrm{pH}$ of the medium, oxidation state and redox potential. In the aqueous environment, inorganic arsenic appears commonly in forms of arsenite (As(III)) and arsenate (As(V)). $\mathrm{pH}$, redox potential and the presence of complexing ions such as ions of sulfur, iron, and calcium determine the arsenic valence and speciation. Figures 5 and 6 contain a summary of the forms of arsenic typically present in water.

In typical drinking water $\mathrm{pH}$ ranges of 6 to 9 , the predominant arsenite species in neutral in charge $\left(\mathrm{H}_{3} \mathrm{AsO}_{3}\right)$ while arsenate species are present as $\left(\mathrm{H}_{2} \mathrm{AsO}_{4}^{-}\right.$and

Table 1 Experimental parameters

\begin{tabular}{|c|c|c|}
\hline Parameters & Chosen parameter ranges & Constant variables \\
\hline Initial pH & $2,3,4,5,6,7,8$ & $\begin{array}{l}\text { initial arsenic concentration: } 50 \mathrm{mg} / \mathrm{L} \text {, current density: } 0.54 \mathrm{~mA} / \mathrm{cm}^{2} \text {, } \\
\text { stirring speed: } 150 \mathrm{rpm}\end{array}$ \\
\hline Current density, $\mathrm{mA} / \mathrm{cm}^{2}$ & $0.18,0.36,0.54,0.71,0.89,1.07$ & initial pH:4, initial arsenic concentration: 50 mg/L, stirring speed: 150 rpm \\
\hline Arsenic concentration, $\mathrm{mg} / \mathrm{L}$ & $10,25,50,100$ & initial pH:4, current density: $0.54 \mathrm{~mA} / \mathrm{cm}^{2}$, stirring speed: $150 \mathrm{rpm}$ \\
\hline Supporting electrolyte type & $15 \mathrm{mM} \mathrm{NaCl}, 15 \mathrm{mM} \mathrm{KCl}, 10 \mathrm{mM} \mathrm{Na}_{2} \mathrm{SO}_{4}$ & $\begin{array}{l}\text { initial } \mathrm{pH}: 4 \text {, initial arsenic concentration: } 50 \mathrm{mg} / \mathrm{L} \text {, current density: } \\
0.54 \mathrm{~mA} / \mathrm{cm}^{2} \text {, stirring speed: } 150 \mathrm{rpm}\end{array}$ \\
\hline Stirring speed, rpm & $50,150,250,350$ & $\begin{array}{l}\text { initial } \mathrm{pH}: 4 \text {, initial arsenic concentration: } 50 \mathrm{mg} / \mathrm{L} \text {, current density: } \\
0.54 \mathrm{~mA} / \mathrm{cm}^{2}\end{array}$ \\
\hline
\end{tabular}




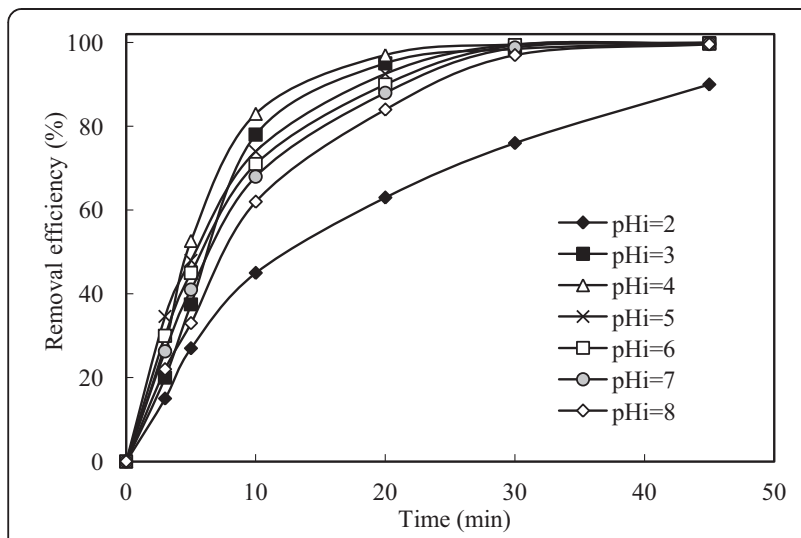

Figure 2 Effect of $\mathrm{pH}$ on the arsenic removal efficiency (initial arsenic concentration: $50 \mathrm{mg} / \mathrm{L}$, current density: $0.54 \mathrm{~mA} / \mathrm{cm}^{2}$ and stirring speed: $150 \mathrm{rpm}$ ).

$\mathrm{HAsO}_{4}^{2-}$ ). In oxygenated waters, $\mathrm{As}(\mathrm{V})$ is dominant, existing in an ionic forms either $\mathrm{H}_{2} \mathrm{AsO}_{4}^{-}$or $\mathrm{HAsO}_{4}^{2-}$ over the $\mathrm{pH}$ range typically encountered in water treatment. Under anoxic conditions, $\mathrm{As}(\mathrm{III})$ is stable with nonionic $\left(\mathrm{H}_{3} \mathrm{AsO}_{3}\right)$ and anionic $\left(\mathrm{H}_{2} \mathrm{AsO}_{3}^{-}\right)$species dominant below and above $\mathrm{pH} 9.2$ [37]. Due to the differences in ionic charge of the arsenite and arsenate particles in the $\mathrm{pH} 6$ to 9 range the neutrally charged arsenite compound $\left(\mathrm{H}_{3} \mathrm{AsO}_{3}\right)$ is difficult to remove when compared to the divalent $\left(\mathrm{HAsO}_{4}^{2-}\right)$ and monovalent arsenate anions $\left(\mathrm{H}_{2} \mathrm{AsO}_{4}^{-}\right)$. The negative charges of the arsenite and arsenate compounds make arsenic easy to remove by adsorptive, co-precipitate and chemical exchange processes. $\mathrm{As}(\mathrm{V})$ species are negatively charged above $\mathrm{pH}$ 2.1, whereas negatively charged As(III) species do not predominate until $\mathrm{pH}$ levels exceed 9.2.

In this study, at initial $\mathrm{pH}$ of 2 , final $\mathrm{pH}$ reached to 3.15 at the end of 30 minutes during the process. At this $\mathrm{pH}$ arsenic was found as nonionic arsenite $\left(\mathrm{H}_{3} \mathrm{AsO}_{3}\right)$ or

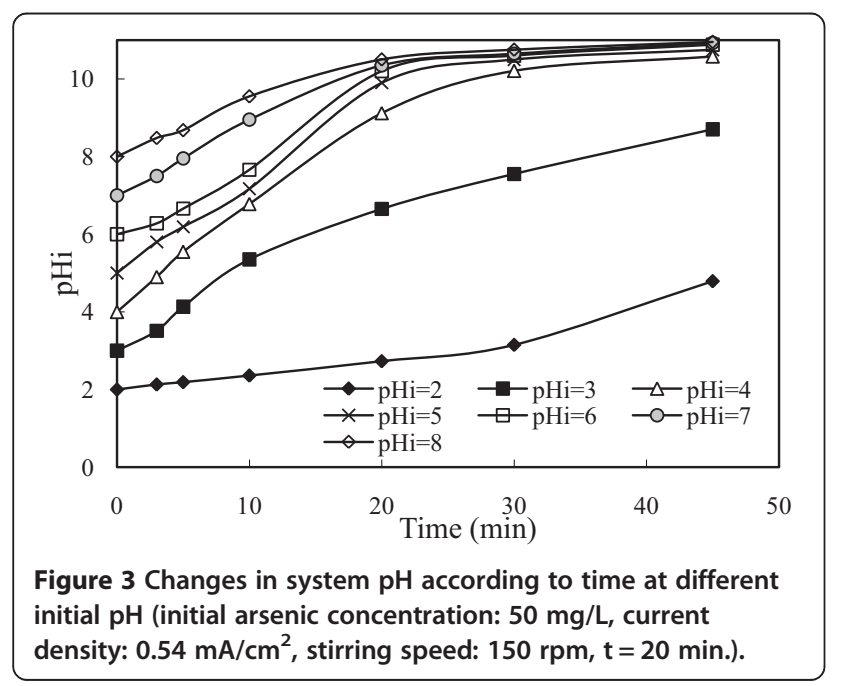

arsenate anions $\left(\mathrm{H}_{2} \mathrm{AsO}_{4}^{-}\right)$. Arsenic removal efficiency was found as $97.91 \%$ at thirtieth minutes so its molecular charge must be negative and arsenic was as $\mathrm{H}_{2} \mathrm{AsO}_{4}{ }^{-}$. At initial $\mathrm{pH}$ of 3, final $\mathrm{pH}$ reached to 7.89 at the end of 30 minutes during the process. At this $\mathrm{pH}$ arsenic was found as nonionic arsenite $\left(\mathrm{H}_{3} \mathrm{AsO}_{3}\right)$ or arsenate anions $\left(\mathrm{H}_{2} \mathrm{AsO}_{4}^{-}\right.$and $\left.\mathrm{HAsO}_{4}^{2-}\right)$. Arsenic removal efficiency was found as $98.42 \%$ at thirtieth minutes so its molecular charge must be negative and arsenic was as $\mathrm{H}_{2} \mathrm{AsO}_{4}{ }^{-}$and $\mathrm{HAsO}_{4}{ }^{2-}$. At initial $\mathrm{pH}$ of 4,5 , 6, final $\mathrm{pH}$ reached to minimum 10.51 and maximum 10.70 at the end of 30 minutes during the process. In the range of $\mathrm{pH} 4.00$ to 10.70 arsenic was found as arsenite $\left(\mathrm{H}_{3} \mathrm{AsO}_{3}, \mathrm{H}_{2} \mathrm{AsO}_{3}{ }^{-}\right)$ or arsenate anions $\left(\mathrm{H}_{2} \mathrm{AsO}_{4}{ }^{-}, \mathrm{HAsO}_{4}{ }^{2-}\right)$. Arsenic removal efficiency was found as over $99 \%$ at thirtieth minutes so its molecular charge must be negative and arsenic was as $\mathrm{H}_{2} \mathrm{AsO}_{3}{ }^{-}, \mathrm{H}_{2} \mathrm{AsO}_{4}{ }^{-}, \mathrm{HAsO}_{4}{ }^{2-}$. At initial $\mathrm{pH}$ of 7 and 8 final $\mathrm{pH}$ reached to 10.74 ve 10.75 respectively at the end of 30 minutes during the process. In the range of $\mathrm{pH} 7.00$ to 10.75 arsenic was found as arsenite $\left(\mathrm{H}_{3} \mathrm{AsO}_{3}, \mathrm{H}_{2} \mathrm{AsO}_{3}{ }^{-}\right)$ or arsenate anions $\left(\mathrm{HAsO}_{4}{ }^{2-}\right)$. Arsenic removal efficiency was found respectively as $98.78 \%$ and $98.00 \%$ at thirtieth minutes so its molecular charge must be negative and arsenic was as $\mathrm{H}_{2} \mathrm{AsO}_{3}{ }^{-}, \mathrm{HAsO}_{4}{ }^{2-}$. It is known that ferric hydroxides have a higher adsorption capacity for $\mathrm{As}(\mathrm{V})$ than for $\mathrm{As}(\mathrm{III})$ when the water $\mathrm{pH}$ is lower than about 8 [38]. Based on this, As(III) might be oxidized to $\mathrm{As}(\mathrm{V})$ and arsenic might be as $\mathrm{HAsO}_{4}{ }^{2-}$. Because of its molecular charge was negative, it pulled the positively charged metal hydroxides electrostatically and arsenic was removed from solution with great efficiency easily [39]. In this electrocoagulation process the removal mechanism of arsenic was: oxidation of $\mathrm{As}(\mathrm{III})$ to $\mathrm{As}(\mathrm{V})$ and subsequent removal by adsorption/co-precipitation with iron (III) hydroxide generated in the process. The reaction of arsenate co-precipitated with or adsorbed by the $(\mathrm{FeOH})$ colloids can be written as [40]:

$$
2 \mathrm{FeOOH}+\mathrm{H}_{2} \mathrm{AsO}_{4}{ }^{-} \rightarrow(\mathrm{FeO})_{2} \mathrm{HAsO}_{4}+\mathrm{H}_{2} \mathrm{O}+\mathrm{OH}^{-}
$$

Electrical energy consumption values were calculated from Eq. (12) and the relationship between the energy consumption and $\mathrm{pH}$ is shown in Figure 7. The lowest energy consumption curve was obtained in the experiments carried out with initial $\mathrm{pH}$ of 2 because the solution had the highest conductivities. Electrical conductivity caused to decrease energy consumption [41]. The $\mathrm{pH}$ of $\mathrm{As}_{2} \mathrm{O}_{3}$ solution containing $50 \mathrm{mg} / \mathrm{L}$ arsenic was about 11.34 and its conductivity was about $460 \mu \mathrm{S} / \mathrm{cm}$. The decreasing $\mathrm{pH}$ of solution by adding $\mathrm{H}_{2} \mathrm{SO}_{4}$ caused to rise of electrical conductivity. Thus, high conductivity values of solution caused to low resistance values and low energy consumption. Also in the initial $\mathrm{pH}$ value of 4 , at the end of 30 

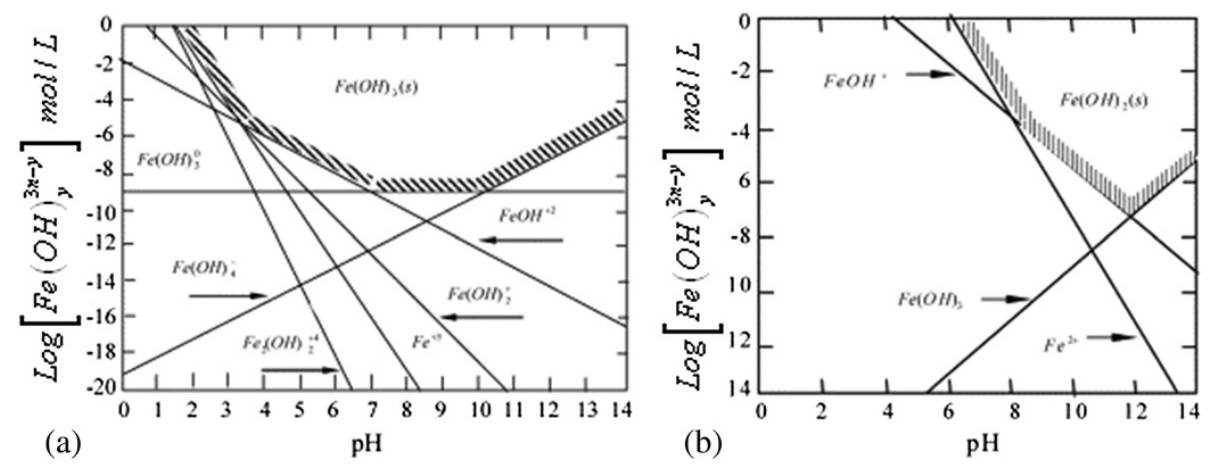

Figure 4 Aqueous-solid phase equilibrium for $\mathrm{Fe}$ (III) (a) and $\mathrm{Fe}(\mathrm{II})$ (b) species at infinite dilution.

minutes it was obtained the highest arsenic removal and low energy consumption $\left(0.33 \mathrm{kWh} / \mathrm{m}^{3}\right)$ so the optimum initial $\mathrm{pH}$ was selected as 4 .

\section{Effect of current density}

The current density is defined as the ratio of current input to the electrolytic cell from the surface area of the electrode. In all electrochemical processes, current density is the most important parameter for controlling the reaction rate within the reactor. It is well known that the amount of current density not only determines the coagulant dosage rate but also the bubble production rate, size and the flocks' growth, which can influence the treatment efficiency of the electrocoagulation [42]. To investigate the effect of current density, a series of experiments performed under conditions in which are given in Table 1 . The results are presented in Figure 8.

Increasing the current density from $0.18 \mathrm{~mA} / \mathrm{cm}^{2}$ to $1.07 \mathrm{~mA} / \mathrm{cm}^{2}$ the arsenic removal efficiency is further improved. The dissolution rate of iron increased with current density increased and thus fixed amount of pollutants reacted to more $\mathrm{Fe}(\mathrm{OH})_{3}$ and so more pollutants were removed. At the higher current density, especially 0.89 and $1.07 \mathrm{~mA} / \mathrm{cm}^{2}$, lower removal efficiency was obtained than expected. The reason of this matter was

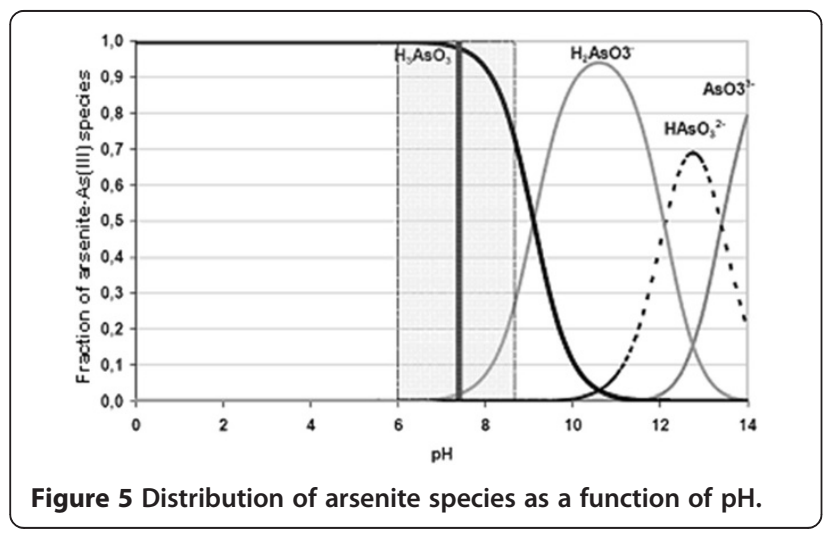

thought that, in experiments high current density applied, on account of the amount of sludge consisted in reactor was too much and enough iron didn't resolution because of the excessive amount of sludge in the minutes following the time is considered.

Although that current density was increased from 0.18 $\mathrm{mA} / \mathrm{cm}^{2}$ to $1.07 \mathrm{~mA} / \mathrm{cm}^{2}$ increased from $88.88 \%$ to 99.68\% of arsenic removal efficiency, energy consumption reached from 0.06 to $1.23 \mathrm{kWh} / \mathrm{m}^{3}$ at the end of 30 minutes. The obtained results for arsenic removal were demonstrated in Figures 8 and 9. High electrical energy consumption with increasing current density was an expected result because energy consumption impressed linearly current density as seen in Eq. 12. Although higher current density caused to solve more electrode material and remove more pollutant, this state was not desired for electrical energy consumption. As shown in Figure 8, same removal efficiency was obtained in the current density of $0.54 \mathrm{~mA} / \mathrm{cm}^{2}$ to $1.07 \mathrm{~mA} / \mathrm{cm}^{2}$ at the end of $30 \mathrm{mi}-$ nutes duration. Since the values were very close to each other, working at current density of $0.54 \mathrm{~mA} / \mathrm{cm}^{2}$ was more appropriate in terms of cost, so current density of $0.54 \mathrm{~mA} / \mathrm{cm}^{2}$ was preferred in experiments.

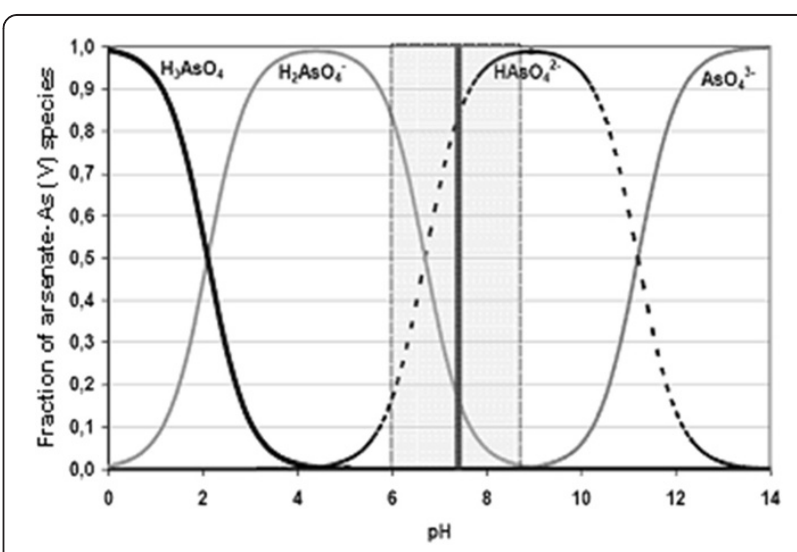

Figure 6 Distribution of arsenate species as a function of $\mathrm{pH}$. 


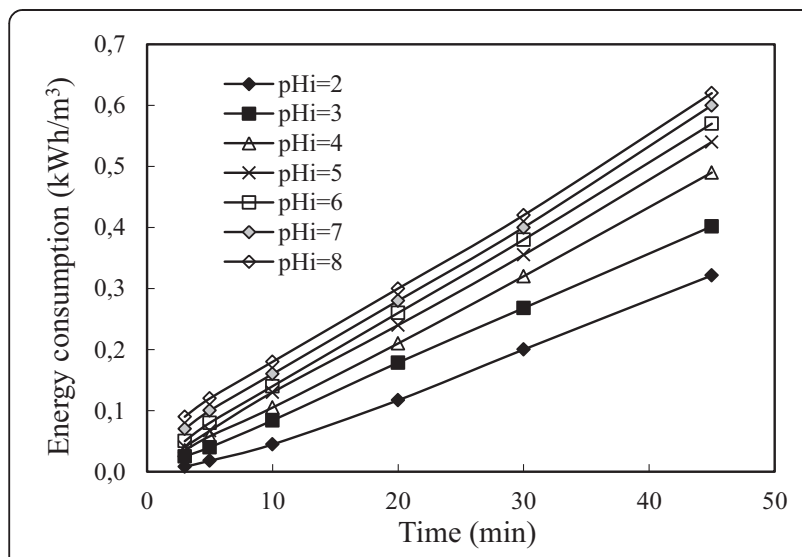

Figure 7 Effect of $\mathrm{pH}$ on the energy consumption (initial arsenic concentration: $50 \mathrm{mg} / \mathrm{L}$, current density: $0.54 \mathrm{~mA} / \mathrm{cm}^{2}$ and stirring speed: $150 \mathrm{rpm}$ ).

\section{Effect of initial arsenic concentration}

To investigate effect of initial arsenic concentration, a series of experiments performed under conditions in which are given in Table 1. The results are presented in Figure 10. The obtained experimental data showed that increasing initial arsenic concentration decreased arsenic removal efficiency. This can be explained as following; although the same amount $\mathrm{Fe}^{3+}$ passed to solution at the same current density for all arsenic concentration, $\mathrm{Fe}^{3+}$ was insufficient for solutions including higher arsenic concentration. The solution conductivity increased with increasing arsenic concentration. As a result of this situation, applied potential and energy consumption decreased. The results obtained were shown graphically in Figure 11.

\section{Effect of supporting electrolyte type}

To investigate this effect, a series of experiments were performed under conditions in which are given in Table 1.

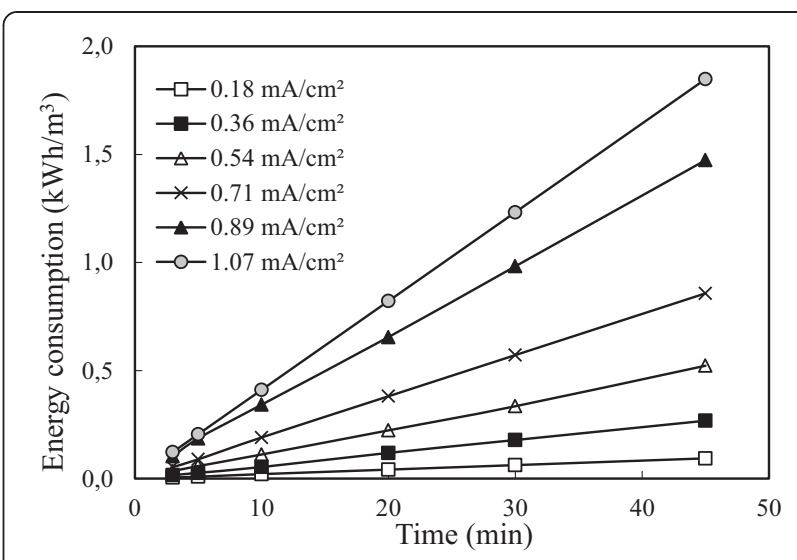

Figure 9 Effect of current density on the energy consumption (initial arsenic concentration: $50 \mathrm{mg} / \mathrm{L}$, initial $\mathrm{pH}: 4$ and stirring speed: $150 \mathrm{rpm}$ ).
The results are presented in Figure 12. Adding supporting electrolyte had not significant effects on the arsenic removal. Supporting electrolyte decreased energy consumption because amounts of ions in solution increased, applied potential decreased and the conductivity of solution increased under constant current density. Electrical energy consumption values were calculated from Eq.12 and the data are shown in Figure 13. The obtained results showed that the most favorable supporting electrolyte type was $\mathrm{Na}_{2} \mathrm{SO}_{4}$ for arsenic removal obtained lowest with $\mathrm{Na}_{2} \mathrm{SO}_{4}$.

\section{Effect of stirring speed}

To investigate stirring speed effect, a series of experiments performed under conditions in which are given in Table 1. The results are presented in Figure 14. Increasing stirring speed decreased arsenic removal efficiency because increasing stirring speed decreased capability of flock formation of iron ions. The stirring speed, smaller than 150

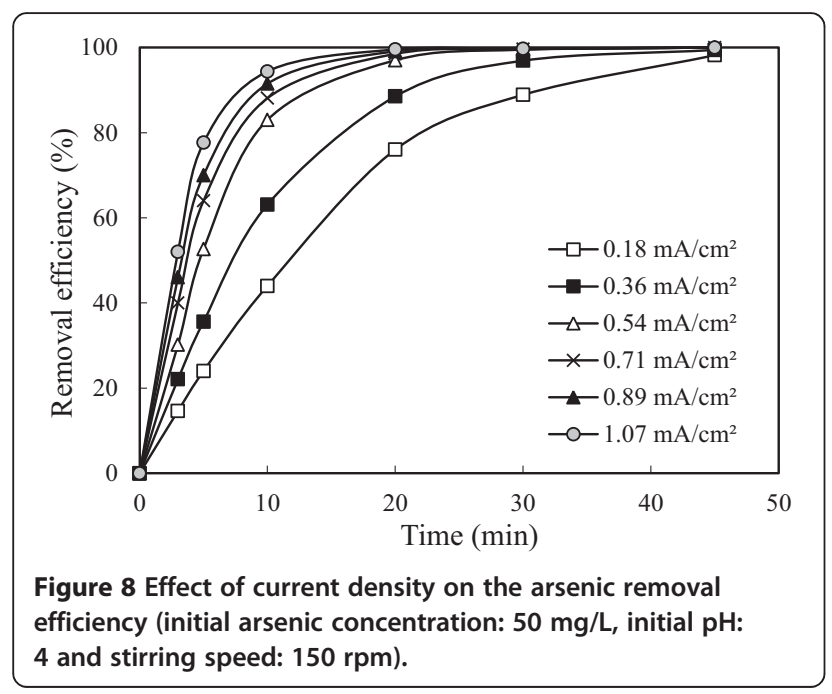

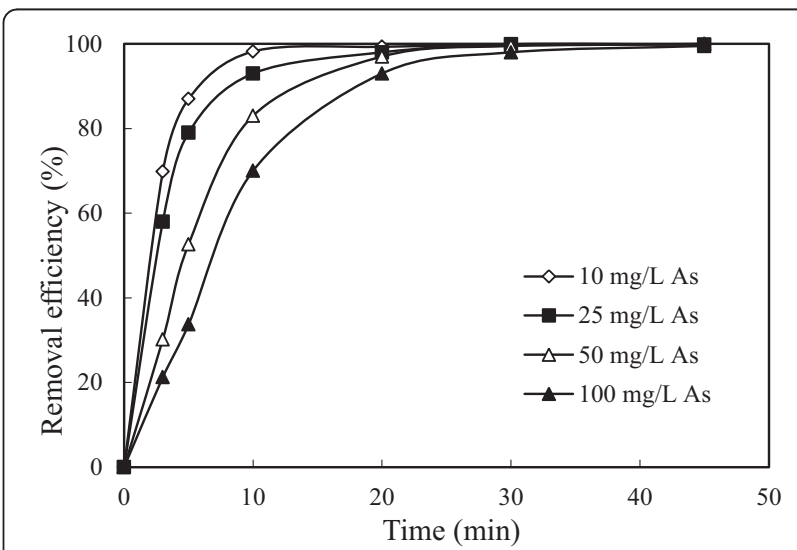

Figure 10 Effect of initial arsenic concentration on the arsenic removal efficiency (initial $\mathrm{pH}: 4$, current density: $0.54 \mathrm{~mA} / \mathrm{cm}^{2}$ and stirring speed: $150 \mathrm{rpm}$ ). 


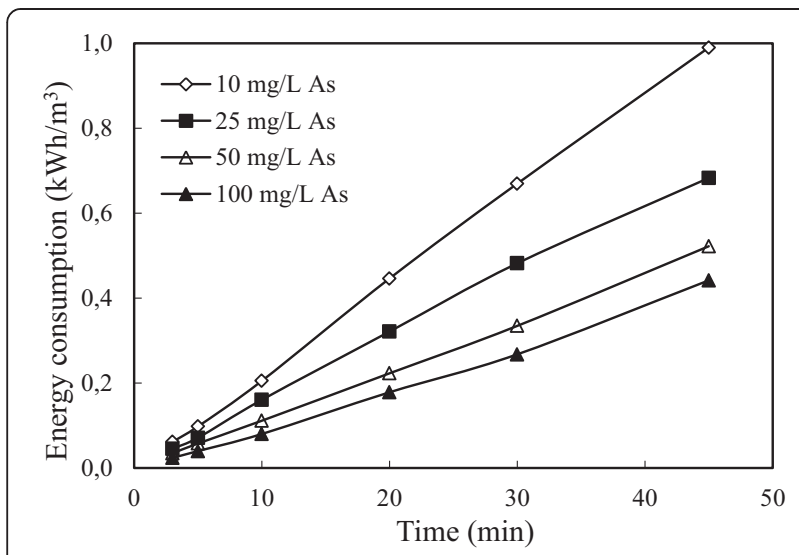

Figure 11 Effect of initial arsenic concentration on the energy consumption (initial pH: 4, current density: $0.54 \mathrm{~mA} / \mathrm{cm}^{2}$ and stirring speed: $150 \mathrm{rpm}$ ).

rpm, decreased arsenic removal efficiency and this speed did not supply a homogeneous mixture in the reactor. The energy consumption values were calculated and were shown in Figure 15. The energy consumption values increased contrary to the arsenic removal efficiency both for the stirring speed above $150 \mathrm{rpm}(250,350 \mathrm{rpm})$ and below $150 \mathrm{rpm}$ (50 rpm). Graphical results showed that the flocks deposited between electrodes because the flocks couldn't mix homogeneously and this deposition caused to the increment of cell resistance at low stirring speed.

The increase in the cell resistance causes the increase of potential value in the systems where constant current density and this causes the increase of the amount of energy consumption per unit volume. It was considered that, the reason of more energy consumption due to the higher stirring speed, is a result of high speed consisted in the reactor created negative pressure on the flow of

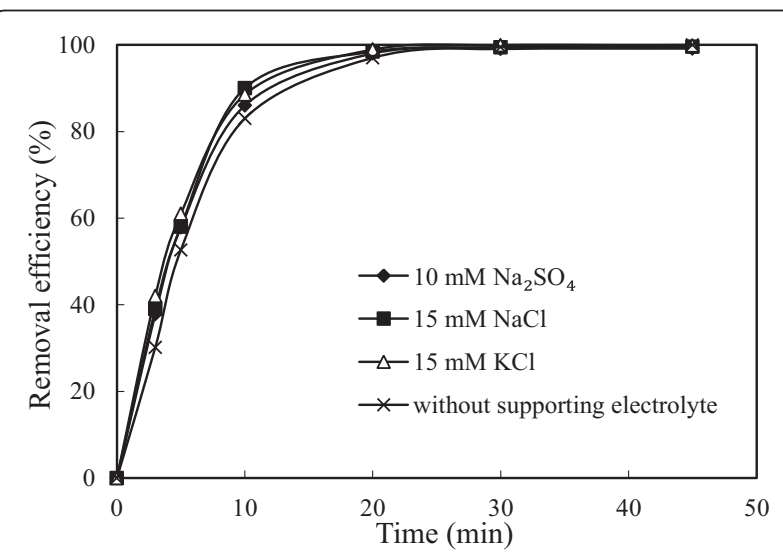

Figure 12 Effect of supporting electrolyte type on the arsenic removal efficiency (initial arsenic concentration: $50 \mathrm{mg} / \mathrm{L}$, initial $\mathrm{pH}: 4$, current density: $0.54 \mathrm{~mA} / \mathrm{cm}^{2}$ and stirring speed: $150 \mathrm{rpm})$.

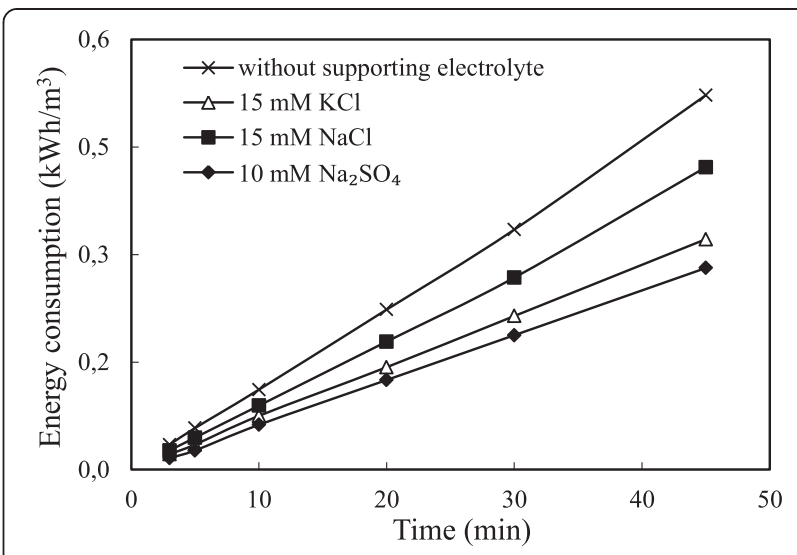

Figure 13 Effect of supporting electrolyte type on the energy consumption (initial arsenic concentration: $50 \mathrm{mg} / \mathrm{L}$, initial $\mathrm{pH}$ : 4, current density: $0.54 \mathrm{~mA} / \mathrm{cm}^{2}$ and stirring speed: $150 \mathrm{rpm}$ ).

electrons which slows the flow of electrons or creates an additional resistance. The stirring speed of 250 and 350 $\mathrm{rpm}$ are good in terms of efficiency but they were not preferred in terms of energy consumption. So the best stirring speed was $150 \mathrm{rpm}$ for arsenic removal.

\section{Conclusions}

The present study clearly demonstrated the applicability of electrocoagulation process using the iron electrode for arsenic removal. The effects of operational parameters such as initial pH, electrolysis time, current density, initial arsenic concentration, supporting electrolyte type and stirring speed on arsenic removal efficiency were studied in detail and explained as well. It has been observed that the $\mathrm{pH}$ is an important operating factor influencing the performance of electrocoagulation process. Optimal initial $\mathrm{pH}$ was found as 4 in the use of iron as sacrificial electrode material in the treatment. Arsenic was as arsenate anions $\left(\mathrm{HAsO}_{4}^{2-}\right)$ and their molecular charge

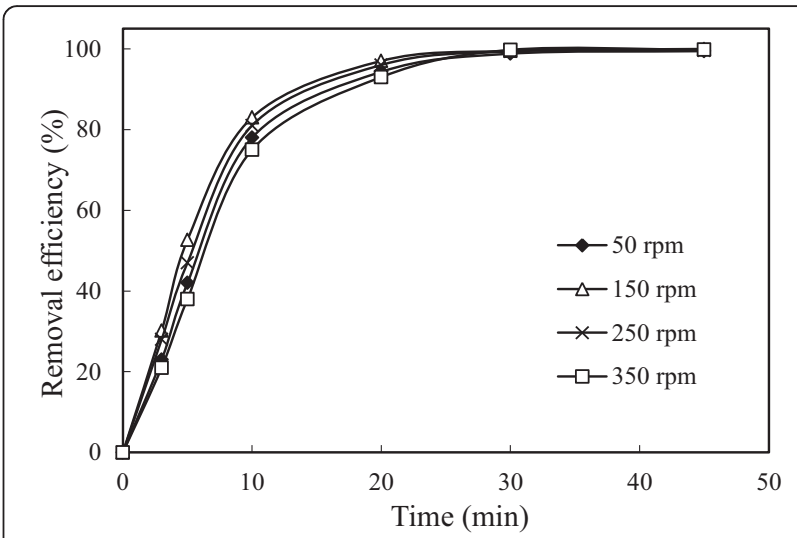

Figure 14 Effect of stirring speed on the arsenic removal efficiency (initial arsenic concentration: $50 \mathrm{mg} / \mathrm{L}$, initial $\mathrm{pH}:$, current density: $0.54 \mathrm{~mA} / \mathrm{cm}^{2}$ ). 


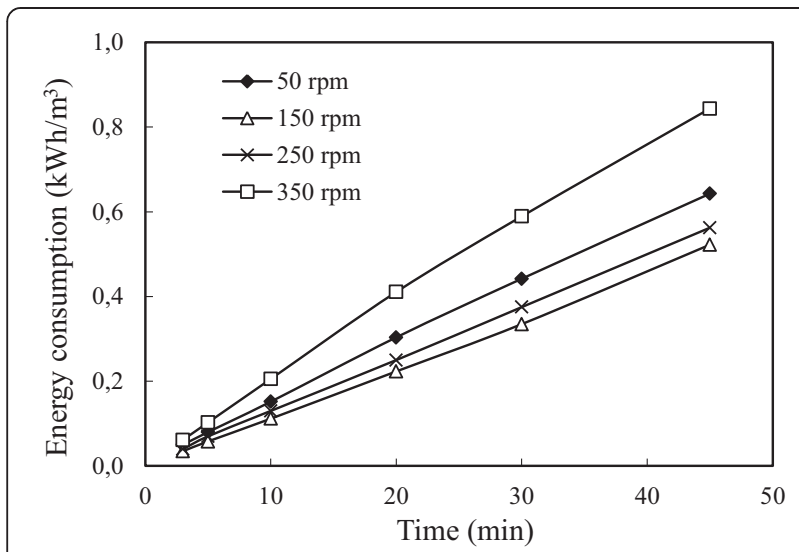

Figure 15 Effect of stirring speed on the energy consumption (initial arsenic concentration: $50 \mathrm{mg} / \mathrm{L}$, initial $\mathrm{pH}$ : 4, current density: $0.54 \mathrm{~mA} / \mathrm{cm}^{2}$.

were negative; they pulled the positively charged metal hydroxides electrostatically so arsenic was removed from solution with great efficiency easily. The removal mechanism of arsenic was oxidation of $\mathrm{As}(\mathrm{III})$ to $\mathrm{As}(\mathrm{V})$ and subsequent removal by adsorption/co-precipitation with iron (III) hydroxide generated in the process. Increasing the current density $0.18 \mathrm{~mA} / \mathrm{cm}^{2}$ to $1.070 \mathrm{~mA} / \mathrm{cm}^{2}$, arsenic removal efficiency increased from $88.88 \%$ to $99.68 \%$, energy consumption reached from 0.06 to $1.23 \mathrm{kWh} / \mathrm{m}^{3}$. Increasing current density increased amount of $\mathrm{Fe}^{3+}$ ions and $\mathrm{Fe}^{3+}$ ions reacted with more arsenic (arsenite or arsenate) ions in aqueous media. Arsenic removal efficiency decreased with increasing arsenic concentration. Increasing arsenic concentration increased conductivity of solution. The higher conductivity values decreased energy consumption. Adding supporting electrolyte had not significant effects on the arsenic removal. Supporting electrolyte decreased energy consumption because amounts of ions in solution increased, applied potential decreased and the conductivity of solution increased under constant current density. Stirring speed affected arsenic removal efficiency. Arsenic removal decreased when both stirring speeds fewer than $150 \mathrm{rpm}$ were not proved homogenization in the reactor. The best stirring speed was 150 $\mathrm{rpm}$ for arsenic removal. Stirring speed above $150 \mathrm{rpm}$ prevented formation of $\mathrm{Fe}(\mathrm{OH})_{3}$ and to react between arsenic and $\mathrm{Fe}^{3+}$ ions species.

As a result under the optimum conditions of an initial $\mathrm{pH}$ of 4 , current density of $0.54 \mathrm{~mA} / \mathrm{cm}^{2}$, stirring speed of $150 \mathrm{rpm}$, electrolysis time of 30 minutes, arsenic removal was obtained as 99.50. Electrical energy consumption in the above conditions was calculated as 0.33 $\mathrm{kWh} / \mathrm{m}^{3}$. Electrocoagulation with iron electrodes was able to bring down $50 \mathrm{mg} / \mathrm{L}$ arsenic concentration to less than $10 \mu \mathrm{g} / \mathrm{L}$ at the end of electrolysis time of 45 minutes with low electrical energy consumption as 0.52
$\mathrm{kWh} / \mathrm{m}^{3}$. It can be concluded from this study that electrocoagulation with iron electrodes is a promising technique for arsenic removal.

\section{Competing interests}

The authors declare that they have no competing interests.

\section{Authors' contributions}

BZC carried out the experiments under the guidance of RB, AEY and BAF. $B Z C, R B, A E Y$ and $B A F$ compiled the experimental data in journal format. All authors read and approved the final manuscript.

\section{Acknowledgements}

The authors are grateful for financial support of Ataturk University Scientific Research Project Department (Project No: 2009/55).

\section{Author details}

${ }^{1}$ Eighth Regional Directorate of State Hydraulic Works (DSi), Erzurum, Turkey. ${ }^{2}$ Department of Environmental Engineering, Engineering Faculty, Atatürk University, Erzurum, Turkey. ${ }^{3}$ Department of Environmental Engineering, Faculty of Engineering, Balıkesir University, Balikesir, Turkey.

Received: 16 December 2012 Accepted: 31 May 2014

Published: 11 June 2014

\section{References}

1. Gomes JAG, Daida P, Kesmez M, Weir M, Moreno H, Parga JR, Irwin G, McWhinney H, Grady T, Peterson E, Cocke DL: Arsenic removal by electrocoagulation using combined Al-Fe electrode system and characterization of products. J Hazard Mater 2007, 139:220-231.

2. Shafiquzzaman M, Azam MS, Nakajima J, Bari QH: Investigation of arsenic removal performance by a simple iron removal ceramic filter in rural households of Bangladesh. Desalination 2011, 265:60-66.

3. Masscheleyn PH, Delaune RD, Patrick WH: Effect of redox potential and pH on arsenic speciation and solubility in a contaminated soil. Environ Sci Technol 1991, 25:1414-1419.

4. Morales KH, Ryan L, Kuo T-L, Wu M-M, Chen C-J: Risk of internal cancers from arsenic in drinking water. Environ Health Persp 2000, 108:655-661.

5. World Health Organization (WHO): Guidelines for drinking-water quality. Volume 1. 3rd edition. Geneva: Recommendations; 2004.

6. Greenleaf JE, Lin J-C, Sengupta AK: Two novel applications of ion exchange fibers: Arsenic removal and chemical-free softening of hard water. Environ Prog 2006, 25:300-311.

7. Anirudhan TS, Unnithan MR: Arsenic (V) removal from aqueous solutions using an anion exchanger derived from coconut coir pith and its recovery. Chemosphere 2007, 66:60-66.

8. Edwards M: Chemistry of arsenic removal during coagulation and Fe-Mn oxidation. Denver, CO, ETATS-UNIS: American Water Works Association; 1994.

9. Bajpai $S$, Chaudhuri M: Removal of arsenic from ground water by manganes dioxide-coated stand. J Environ Eng 1999, 125:782-784.

10. Far $L B$, Souri $B$, Heidari M, Roshan K: Evaluation of iron and manganesecoated pumice application for the removal of as(v) from aqueous solutions. Iran J Environ Health Sci Engineer 2012, 9:21.

11. Nasseri S, Heidari M: Evaluation and comparison of aluminum-coated pumice and zeolite in arsenic removal from water resources. Iran J Environ Health Sci Engineer 2012, 9:1-7.

12. Ratna Kumar P, Chaudhari S, Khilar KC, Mahajan SP: Removal of arsenic from water by electrocoagulation. Chemosphere 2004, 55:1245-1252.

13. Basha CA, Selvi SJ, Ramasamy E, Chellammal S: Removal of arsenic and sulphate from the copper smelting industrial effluent. Chem Eng J 2008, 141:89-98.

14. Parga JR, Cocke DL, Valenzuela JL, Gomes JA, Kesmez M, Irwin G, Moreno H, Weir M: Arsenic removal via electrocoagulation from heavy metal contaminated groundwater in La Comarca Lagunera México. J Hazard Mater 2005, 124:247-254

15. Hansen HK, Núñez $P$, Grandon R: Electrocoagulation as a remediation tool for wastewaters containing arsenic. Miner Eng 2006, 19:521-524.

16. Weng Y-H, Chaung-Hsieh LH, Lee H-H, Li K-C, Huang CP: Removal of arsenic and humic substances (HSs) by electro-ultrafiltration (EUF). J Hazard Mater 2005, 122:171-176. 
17. Iqbal J, Kim H-J, Yang J-S, Baek K, Yang J-W: Removal of arsenic from groundwater by micellar-enhanced ultrafiltration (MEUF). Chemosphere 2007, 66:970-976.

18. Kim DH, Kim KW, Cho J: Removal and transport mechanisms of arsenics in UF and NF membrane processes. J Water Health 2006, 4:215-223.

19. Ribeiro AB, Mateus EP, Ottosen LM, Bech-Nielsen G: Electrodialytic removal of $\mathrm{Cu}, \mathrm{Cr}$, and as from chromated copper arsenate-treated timber waste. Environ Sci Technol 2000, 34:784-788.

20. Ning RY: Arsenic removal by reverse osmosis. Desalination 2002, 143:237-241.

21. Gholami MM, Mokhtari MA, Aameri A, Fard MRA: Application of reverse osmosis technology for arsenic removal from drinking water. Desalination 2006, 200:725-727.

22. Iberhan L, Wisniewski M: Removal of arsenic(III) and arsenic(V) from sulfuric acid solution by liquid-liquid extraction. J Chem Technol Biot 2003, 78:659-665.

23. Katsoyiannis I, Zouboulis A, Althoff H, Bartel H: As(III) removal from groundwaters using fixed-bed upflow bioreactors. Chemosphere 2002, 47:325-332.

24. Gihring TM, Druschel GK, McCleskey RB, Hamers RJ, Banfield JF: Rapid arsenite oxidation by thermus aquaticus and thermus thermophilus: field and laboratory investigations. Environ Sci Technol 2001, 35:3857-3862.

25. Kobya M, Senturk E, Bayramoglu M: Treatment of poultry slaughterhouse wastewaters by electrocoagulation. J Hazard Mater 2006, 133:172-176.

26. Taheri M, Moghaddam M, Arami M: Optimization of Acid Black 172 decolorization by electrocoagulation using response surface methodology. Iran J Environ Health Sci Engineer 2012, 9:1-8

27. Nielson K, Smith DW: Ozone-enhanced electroflocculation in municipal wastewater treatment. J Environ Eng and Science 2005, 4:65-76.

28. Mollah MYA, Schennach R, Parga JR, Cocke DL: Electrocoagulation (EC) - science and applications. J Hazard Mater 2001, 84:29-41.

29. Rajeshwar K, Ibanez JG: Environmental electrochemistry: Fundamentals and applications in pollution abatement. San Diego: Academic Press; 1997.

30. Ihos M, Negrea A, Lupa L, Ciopec M, Negrea P: Comparative study of As (III) removal efficiency from water by electrocoagulation and conventional coagulation. Chem Bull "Politehnica" 2005, 50:87-90.

31. Balasubramanian N, Kojima T, Ahmed Basha C, Srinivasakannan C: Removal of arsenic from aqueous solution using electrocoagulation. J Hazard Mater 2009, 167:966-969.

32. Holak W: Gas-sampling technique for arsenic determination by atomic. absorption spectrophotometry. Anal Chem 1969, 41:1712-1713.

33. Howard GA: (Boro)Hydride techniques in trace element speciation. J Anal Atom Spectrom 1997, 12:267-272.

34. Irdemez S: The phosphate removal from wastewater by electrocoagulation, in: Institute of Science and Technology. Erzurum, Turkey: Atatürk University; 2005.

35. Benefield LD, Judkins JF, Weand BL: Processes chemistry for water and wastewater treatment. Englewood Cliffs New Jersey: Prentice-Hall Inc; 1982

36. Lin T-F, Wu J-K: Adsorption of arsenite and arsenate within activated alumina grains: equilibrium and kinetics. Water Res 2001, 35:2049-2057.

37. Chowdhury Z, Kommineni S, Narasimhan R, Brereton J, Amy G, Sinha S: Implementation of arsenic treatment systems-Part 1. Process selection. Denver: AWWA Research Foundation and American Water Works Association (Hrsg); 2002.

38. Meng X, Bang S, Korfiatis GP: Effects of silicate, sulfate, and carbonate on arsenic removal by ferric chloride. Water Res 2000, 34:1255-1261.

39. Johnston R, Heijnen H: Safe Water Technology for Arsenic Removal, in: Technologies for Arsenic Removal from Drinking Water. Tokyo: Bangladesh University of Engineering and Technology, Dhaka, Bangladesh and the United Nations University; 2001.

40. Chen G: Electrochemical technologies in wastewater treatment. Sep Purif Technol 2004, 38:11-41.

41. Yilmaz AE, Boncukcuoğlu R, Kocakerim MM: An empirical model for parameters affecting energy consumption in boron removal from boron-containing wastewaters by electrocoagulation. J Hazard Mater 2007, 144:101-107.

42. Yilmaz AE, Boncukcuoğlu R, Kocakerim MM, Yilmaz MT, Paluluoğlu C: Boron removal from geothermal waters by electrocoagulation. $J$ Hazard Mater 2008, 153:146-151.

\section{doi:10.1186/2052-336X-12-95}

Cite this article as: Can et al:: Effect of some operational parameters on the arsenic removal by electrocoagulation using iron electrodes. Journal of Environmental Health Science \& Engineering 2014 12:95.

\section{Submit your next manuscript to BioMed Central and take full advantage of:}

- Convenient online submission

- Thorough peer review

- No space constraints or color figure charges

- Immediate publication on acceptance

- Inclusion in PubMed, CAS, Scopus and Google Scholar

- Research which is freely available for redistribution 